\title{
PERAN BURNOUT MEMEDIASI PENGARUH STRES KERJA TERHADAP TURNOVER INTENTION KARYAWAN KUTABEX BEACH FRONT HOTEL BALI
}

\author{
Ni Putu Mas Nadia Sintyadewi ${ }^{1}$ \\ I Gusti Ayu Manuati Dewi ${ }^{2}$
}

\author{
${ }^{1,2}$ Fakultas Ekonomi dan Bisnis, Universitas Udayana, Bali-Indonesia \\ email: dewisintya40@gmail.com
}

\begin{abstract}
ABSTRAK
Penelitian ini bertujuan untuk menganalisis pengaruh stres kerja terhadap turnover intention dengan burnout sebagai variabel mediasi. Lokasi penelitian adalah di Kutabex Beach Front Hotel Bali. Populasi pada penelitian ini berjumlah 109 karyawan dengan sampel sebanyak 86 orang ditentukan melalui Rumus Slovin. Metode penentuan sampel adalah proportionate random sampling. Teknik analisis yang diterapkan untuk pengujian hipotesis adalah Path Analysis. Hasil penelitian menunjukkan stres kerja berpengaruh positif dan signifikan terhadap burnout dan turnover intention. Burnout berpengaruh positif dan signifikan terhadap turnover intention. Selanjutnya burnout secara signifikan memediasi pengaruh stres kerja terhadap turnover intention. Temuan penelitian ini memberikan implikasi terhadap strategi pengembangan sumber daya manusia di Kutabex Beach Front Hotel Bali untuk lebih memperhatikan karyawan agar tidak memiliki niat untuk meninggalkan perusahaan.
\end{abstract}

Kata Kunci: stres kerja, burnout, turnover intention.

\begin{abstract}
This study aims to analyze the effect of work stress on turnover intention with burnout as a mediating variable. The research location is Kutabex Beach Front Hotel Bali. The population in this study amounted to 109 employees with 86 samples using the Slovin Formula. The sample selection method is proportionate random sampling. The analysis technique applied for hypothesis testing is Path Analysis. The results showed that work stress had a positive and significant effect on burnout and turnover intention. Burnout has a positive and significant effect on turnover intention. Furthermore burnout significantly mediates the effect of work stress on turnover intention. The findings of this study have implications for the strategy of developing human resources at Kutabex Beach Front Hotel Bali to pay more attention to employees so they do not have the intention to leave the company.

Keywords: work stress, burnout, turnover intention
\end{abstract}




\section{PENDAHULUAN}

Menurut Ardana et al. (2012) sumber daya manusia (SDM) adalah harta atau aset yang paling berharga dan yang paling penting dimiliki oleh suatu organisasi, karena keberhasilan organisasi sangat ditentukan oleh unsur manusia. Widodo (2015) menyatakan perusahaan harus mampu mengelola SDM dengan baik guna mencapai visi dan misi perusahaan. Suatu organisasi seharusnya tidak dipisahkan dengan pekerja karena mereka yang memainkan peranan dalam menentukan kemajuan, kelancaran, keuntungan dan keberhasilan organisasi (Eduard, 2011).

Menurut Chandio et al. (2013) ketika stres kerja meningkat akan menyebabkan timbulnya keinginan keluar yang ada pada diri karyawan. Stres kerja merupakan isu utama yang menjadi perhatian karena telah menjadi bagian dari kehidupan karyawan dan sulit untuk menghindari stres dari pekerjaan (Parvaiz et al., 2015). Stres di tempat kerja akhir-akhir ini telah menjadi masalah yang serius bagi manajemen perusahaan didalam dunia bisnis (Hlatywayo et al., 2014). Menurut Mangkunegara (2011) stres kerja ini dapat menimbulkan perasaan tidak tenang, kecemasan, emosi yang tidak stabil, sulit tidur, merokok yang berlebihan, suka menyendiri, kurang rileks, gugup dan mengalami peningkatan tekanan darah.

Maharani \& Triyoga (2012) menyatakan burnout merupakan gejala kelelahan emosional yang disebabkan oleh tingginya tuntutan pekerjaan, yang sering dialami individu yang bekerja pada situasi dimana ia harus melayani kebutuhan orang banyak. Burnout merupakan respon yang berkepanjangan terkait faktor penyebab stres yang terus-menerus terjadi di tempat kerja yang di mana hasilnya merupakan perpaduan antara pekerja dan pekerjaannya (Gonul \& Ceyhun, 2014). Burnout bisa terjadi tidak hanya karena dipengaruhi oleh faktor-faktor lingkungan saja, tetapi juga dipengaruhi oleh faktor-faktor individual atau faktor internal, seperti tingkat stres, kemampuan bekerja, pengetahuan dan keterampilan yang dimiliki oleh seseorang (Madziatul, 2011).

Turnover Intention adalah sebuah tujuan seorang individu untuk meninggalkan atau tetap berada dalam suatu organisasi (Tienne et al., 2012). Turnover intention adalah masalah serius pada bidang manajemen sumber daya manusia yang berhubungan dengan rotasi pekerja yang besar (Kumar et al., 2012). Menurut Sidharta (2011) turnover intention adalah suatu bentuk dari karyawan untuk menarik diri pada dunia kerja dan karyawan tersebut juga memiliki hak untuk menentukan keputusan untuk tetap bekerja atau mengundurkan diri dari perusahaan.

Satriyo \& Survival (2014) mengemukakan bahwa adanya pengaruh stres kerja terhadap burnout. Mitchell et al. (2014) mengemukakan bahwa stres kerja merupakan penyebab utama timbulnya turnover intention bagi karyawan maka stres kerja memiliki pengaruh yang positif terhadap turnover intention. Zhang \& Feng (2011) menunjukkan bahwa terdapat pengaruh hubungan signifikan dan positif burnout terhadap turnover intention. Tawiah et al. (2016) menyatakan bahwa stres kerja berpengaruh positif dan signifikan terhadap turnover intention dengan mediasi variabel burnout.

Penelitian ini dilakukan di Kutabex Beach Front Hotel Bali. Kutabex Beach Front Hotel Bali merupakan salah satu hotel yang terletak di Kuta, Badung. Kutabex Beach Front Hotel Bali merupakan sebuah hotel yang menyediakan 
fasilitas menginap yang nyaman bagi para tamu. Kutabex Beach Front Hotel Bali dalam menjalankan suatu operasional tentu diperlukan sumber daya manusia dalam jumlah yang banyak. Tinggi nya tingkat turnover pada karyawan Kutabex Beach Front Hotel Bali menunjukkan angka di atas batas normal. Yuda \& Ardana, (2017) menyatakan bahwa apabila turnover karyawan dikatakan normal apabila berkisar 5-10 persen pertahun dan dikatakan tinggi apabila lebih dari 10 persen. Data jumlah karyawan dan turnover karyawan tahun 2017-2018 Kutabex Beach Front Hotel Bali dapat dilihat pada Tabel 1.

Tabel 1.

Turnover Karyawan Kutabex Beach Front Hotel Bali Tahun 2017-2018

\begin{tabular}{cccccc}
\hline Tahun & $\begin{array}{c}\text { Jumlah } \\
\text { Karyawan } \\
\text { Awal } \\
\text { Tahun }\end{array}$ & $\begin{array}{c}\text { Jumlah } \\
\text { Karyawan } \\
\text { Akhir } \\
\text { Tahun }\end{array}$ & $\begin{array}{c}\text { Jumlah } \\
\text { Karyawan } \\
\text { Masuk }\end{array}$ & $\begin{array}{c}\text { Jumlah } \\
\text { Karyawan } \\
\text { Keluar }\end{array}$ & $\begin{array}{c}\text { Turnover } \\
\text { Karyawan }\end{array}$ \\
\hline 2017 & 110 & 108 & 10 & 12 & 11,00 \\
2018 & 108 & 108 & 14 & 14 & 12,96 \\
\hline
\end{tabular}

Sumber: Human Resources Departement Kutabex Beach Front Hotel Bali, 2019 (diolah)

Dari Tabel 1. dapat mengindikasikan bahwa terdapat masalah turnover karyawan yang serius, karena dapat menimbulkan efek yang buruk bagi Kutabex Beach Front Hotel Bali antara lain timbulnya keinginan untuk mencari pekerjaan atau perusahaan lain karena tidak cocok dengan perusahaan sebelumnya atau dikarenakan adanya tekanan turnover intention. Dengan tingginya tingkat turnover karyawan Kutabex Beach Front Hotel Bali selama 2 tahun berturut-turut, terbuka kemungkinan adanya peningkatan turnover yang tinggi ditahun-tahun berikutnya pada karyawan Kutabex Beach Front Hotel Bali. Hasil wawancara pihak Human Resources Departement Kutabex Beach Front Hotel Bali mengatakan bahwa karyawan yang keluar ini disebabkan tertekan saat bekerja. Pekerjaan yang dirasakan karyawan sangat berat karena harus mencapai target yang telah ditentukan. Hasil wawancara dengan karyawan menyatakan bahwa karyawan sering merasakan kelelahan emosional seperti kurangnya perhatian dari pihak atasan terhadap pihak bawahan. Hal ini menyebabkan adanya niat untuk keluar dari Kutabex Beach Front Hotel Bali.

Penelitian ini bertujuan untuk menganalisis pengaruh stres kerja terhadap burnout pada karyawan di Kutabex Beach Front Hotel Bali, menganalisis pengaruh stres kerja terhadap turnover intention pada karyawan di Kutabex Beach Front Hotel Bali, menganalisis pengaruh burnout terhadap turnover intention pada karyawan di Kutabex Beach Front Hotel Bali dan menganalisis burnout memediasi pengaruh stres kerja terhadap turnover intention pada karyawan di Kutabex Beach Front Hotel Bali.

Teori Pertukaran sosial (Social Exchange Theory) didefinisikan sebagai teori pertukaran antara bagaimana individu berinteraksi dalam kelompok organisasi (Coyle dan Parzefall, 2008). Menurut Jia et al. (2014) teori pertukaran sosial adalah teori yang meneliti tentang pengaruh hubungan organisasi dengan karyawan. Fung et al. (2012) menyatakan bahwa teori pertukaran sosial adalah karyawan yang telah diperlakukan dengan baik oleh organisasi, mereka akan lebih memberikan timbal 
balik yang lebih positif terhadap organisasi. Teori pertukaran sosial oleh Blau (1964), merupakan sebuah organisasi dapat melakukan tindakan positif terhadap karyawan dengan harapan bahwa inisiatif tersebut akan mendapat balasan dalam hal kesetiaan terhadap organisasi, sehingga dapat mengurangi niat karyawan untuk berpindah (turnover intention). Teori ini menekankan efek timbal balik pada hubungan jangka panjang di antara para pemangku kepentingan dalam organisasi (misalnya, karyawan dan manajer) (Paillé \& Mejia-Morelos, 2014).

Menurut hasil penelitian Kreitner \& Kinicki (2004) menunjukkan bahwa salah satu hasil dari stres secara psikologis adalah burnout. Hubungan antara job stress dan burnout juga diteliti oleh Enshassi \& Alkilani (2015) yang menunjukkan organizational stressor sebagai contributor paling besar terhadap meningkatnya physical stress, behavioral stress, dan job burnout. Satriyo \& Survival (2014) mengemukakan bahwa adanya pengaruh stres kerja terhadap burnout. Hobfoll (1989) menunjukkan bahwa stres yang luar biasa tinggi atau kronis akan mempengaruhi individu sehingga mengalami kelelahan (burnout). Tawiah et al., (2016) menunjukkan bahwa stres kerja berpengaruh positif signifikan terhadap burnout.

$\mathrm{H}_{1}$ : Stres kerja berpengaruh positif dan signifikan terhadap burnout

Penelitian yang dilakukan oleh Mitchell et al. (2014) mengemukakan bahwa stres kerja merupakan penyebab utama timbulnya turnover intention bagi karyawan, maka stres kerja memiliki pengaruh yang positif terhadap turnover intention. (Rehman \& Mubashar (2017)) melakukan penelitian dalam industri perhotelan (hospitality) pada tahun 2017 dan menemukan bahwa stres kerja memiliki hubungan yang positif dan signifikan terhadap turnover intention. Parvaiz et al. (2015) menemukan bahwa stres kerja memiliki pengaruh yang positif terhadap turnover intention. Hasil yang sama didapatkan oleh Mosadeghrad (2012); Shahzad et al. (2011) bahwa stres kerja berpengaruh positif terhadap turnover intention karyawan, dimana semakin tinggi tingkat stres kerja maka semakin tinggi juga tingkat turnover intention yang terjadi. Siddiqui \& Raja (2015) dalam penelitiannya menunjukan bahwa stres kerja berpengaruh positif dan signifikan terhadap turnover intention karena tekanan yang berlebihan yang membuat karyawan berfikir untuk meninggalkan organisasi. Menurut Akinboye \& Adeyemo (2002), stres kerja berpengaruh positif dan signifikan terhadap turnover intention. Syahronica et al. (2015) menyatakan semakin banyaknya kebutuhan hidup yang harus terpenuhi dan persaingan kerja yang semakin ketat dapat menimbulkan stres kerja yang akhirnya memicu turnover intention karyawan. Nazenin \& Palupiningdyah (2014) juga menyatakan bahwa stres kerja berpengaruh positif terhadap turnover intention.

$\mathrm{H}_{2}$ : Stres kerja berpengaruh positif dan signifikan terhadap turnover intention

Menurut Weisberg (1994) menemukan terdapat hubungan positif antara burnout dengan turnover intention. Sakka (2016) menemukan variabel burnout memiliki hubungan positif dengan turnover intention, hubungan tersebut dibuktikan dalam pernyataan Sakka bahwa turnover intention berperan sebagai konsekuensi dari fenomena burnout. Liu \& Lo (2017) menemukan bahwa burnout berpengaruh positif signifikan terhadap turnover intention. Zhang \& Feng (2011) menunjukkan bahwa terdapat pengaruh burnout signifikan dan positif terhadap 
turnover intention. Jacob (1994) menemukan dukungan untuk hubungan antara burnout dan penarikan tenaga kerja, salah satunya adalah perputaran tenaga kerja. $\mathrm{H}_{3}$ : Burnout berpengaruh positif dan signifikan terhadap Turnover Intention.

Lee \& Ashforth (1993) dalam studi longitudinal untuk memeriksa efek dari stres kerja pada turnover intention mengusulkan bahwa dari dua aspek burnout yaitu depersonalisasi dan kelelahan emosional akan dikaitkan dengan turnover intention. Lin et al. (2013) melakukan studi untuk menyelidiki hubungan antara burnout, stres kerja, dan turnover intention antara karyawan manajerial. Fried et al. (2008) mengatakan bahwa kemunculan stres ditempat kerja akan mengarahkan karyawan pada ketidakpuasan kerja, saat karyawan merasa tidak puas terhadap pekerjaannya, ia akan cenderung menjadi burnout, akibatnya karyawan akan cenderung memilih untuk meninggalkan pekerjaannya. Kim (2008) menunjukkan bahwa stres berpengaruh positif terhadap burnout tetapi tidak secara langsung berpengaruh terhadap turnover intention, burnout memiliki pengaruh yang positif terhadap turnover intention. Tawiah et al. (2016) menyatakan bahwa stres kerja berpengaruh positif dan signifikan terhadap turnover intention dengan mediasi variabel burnout. Ahmad \& Afgan (2016) mengatakan bahwa kelelahan emosional sebagian memediasi hubungan antara stres kerja dan turnover intention.

$\mathrm{H}_{4}$ : Burnout memediasi stres kerja terhadap turnover intention.

Berdasarkan perumusan hipotesis, kerangka konseptual dapat dilihat pada Gambar 1.

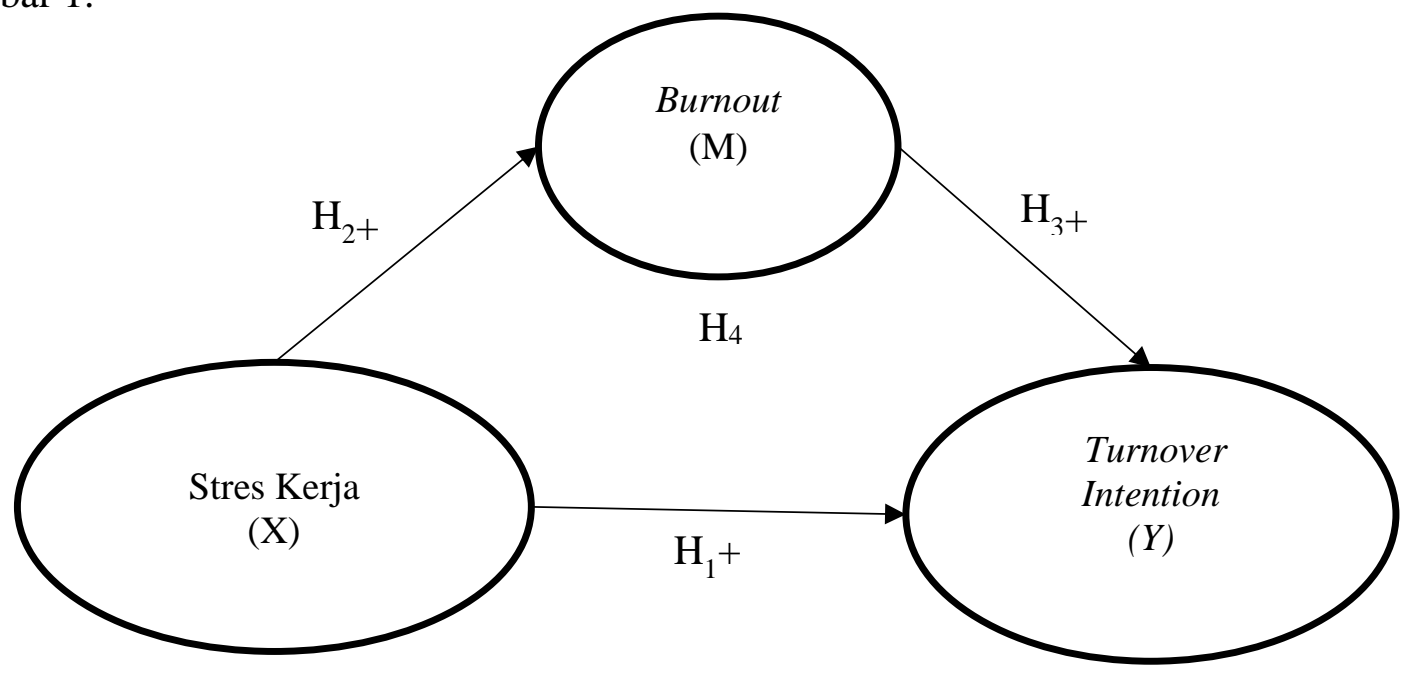

Gambar 1. Kerangka Konseptual

Sumber: Data diolah, 2019

\section{METODE PENELITIAN}

Pendekatan yang digunakan dalam penelitian ini adalah pendekatan kuantitatif yang berbentuk asosiatif (kausalitas). Penelitian ini bertempat pada Kutabex Beach Front Hotel Bali yang beralamat di Jalan Pantai Kuta, Banjar Pande Mas, Kuta, Badung. Penelitian ini dilakukan di Kutabex Beach Front Hotel Bali karena ditemukan adanya masalah yang terkait dengan turnover intention karyawan. Obyek penelitian ini adalah stres kerja, burnout dan turnover intention. 
Variabel eksogen dalam penelitian ini adalah stres kerja (X). Variabel endogen dalam penelitian ini adalah turnover intention (Y). Variabel mediasi dalam penelitian ini adalah burnout (M).

Turnover Intention adalah keinginan karyawan Kutabex Beach Front Hotel Bali untuk keluar atau meninggalkan perusahaan karena alasan tertentu. Adenguga et al., (2013) menyatakan turnover intention mempunyai 3 indikator sebagai dasar mengukur keinginan untuk keluar dari organisasi yaitu 1) munculnya keinginan untuk mencari pekerjaan baru, 2) munculnya keinginan untuk meninggalkan perusahaan, 3) keinginan untuk meninggalkan perusahaan dalam kurun waktu beberapa bulan mendatang.

Stres kerja merupakan kondisi tertekan yang dialami karyawan pada Kutabex Beach Front Hotel Bali di dalam perusahaan terhadap pekerjaannya. Menurut Qureshi et al. (2012) terdapat delapan indikator untuk mengukur stres kerja adalah 1) Tekanan dalam pekerjaan, yaitu perasaan karyawan yang tertekan saat melakukan pekerjaan. Indikator ini diukur dari tanggapan karyawan yang sering merasa tertekan dalam pekerjaan. 2) Kesulitan dalam pekerjaan, yaitu perasaan kesulitan saat melakukan pekerjaan. Indikator ini diukur dari tanggapan karyawan yang sering mengeluh kesulitan tidur akibat pekerjaan selama diperusahaan terasa sulit. 3) Pekerjaan membuat individu gelisah, yaitu keadaan karyawan yang merasakan kegelisahan saat bekerja di suatu perusahaan dikarenakan target yang harus dipenuhi. Indikator ini diukur dari tanggapan karyawan bahwa pekerjaannya sering membuat karyawan menjadi gelisah. 4) Kelelahan saat bekerja, yaitu keadaan karyawan merasa lelah saat melakukan pekerjaan di perusahaan. Indikator ini diukur dari tanggapan karyawan yang sering merasa lelah setelah bekerja setiap hari. 5) Membantu kesehatan apabila merubah pekerjaan, yaitu pemikiran karyawan terhadap pekerjaan yang membuat kesehatannya memburuk. Indikator ini diukur dari tanggapan apabila karyawan berganti pekerjaan akan sangat membantu kesehatan karyawan. 6) Lemah saat bekerja, yaitu keadaan karyawan yang merasa tidak mampu menyelesaikan pekerjaannya. Indikator ini diukur dari tanggapan karyawan yang sering merasa lemah saat bekerja. 7) Emosional dalam bekerja, yaitu keadaan karyawan yang tidak dapat mengontrol emosi dalam bekerja dikarenakan mengalami tekanan dalam bekerja. Indikator ini diukur dari tanggapan karyawan yang sering merasa lebih emosional di tempat bekerja. 8)Tidak bahagia di tempat kerja, yaitu pemikiran karyawan yang merasa tidak menemukan kebahagian selama bekerja di perusahaan tersebut. Indikator ini diukur dari tanggapan karyawan yang sering merasa tidak bahagia di tempat kerja.

Burnout merupakan bentuk dari kelelahan yang dirasakan oleh karyawan Kutabex Beach Front Hotel Bali yang disebabkan karena bekerja terlalu intens, berdedikasi dan berkomitmen, bekerja terlalu lama serta memandang kebutuhan dan keinginan mereka sebagai hal kedua. Menurut Maslach (1981) terdapat tiga indikator yakni 1) Kelelahan emosional adalah menggambarkan perasaan menjadi terlalu emosional dan lelah oleh pekerjaan seseorang. 2) Depersonalisasi adalah menggambarkan respons yang tidak berperasaan dan impersonal terhadap penerima perawatan atau layanan seseorang. 3) Kemunduran kepribadian (personal accomplishment) adalah menggambarkan perasaan kompetensi dan keberhasilan dalam pekerjaan seseorang dengan orang lain. 
Populasi dalam penelitian ini adalah 109 karyawan yang bekerja pada Kutabex Beach Front Hotel Bali. Sampel yang diambil dalam penelitian ini sebanyak 86 karyawan. Teknik sampling yang digunakan dalam penelitian ini adalah proportionate random sampling digunakan untuk menentukan jumlah sampel bila populasi mempunyai anggota atau unsur yang tidak homogen dan berstrata secara proporsional (Sugiyono, 2017). Jumlah sampel dalam penelitian ini ditentukan berdasarkan pendekatan Slovin. Rumus Slovin yang digunakan adalah sebagai berikut.

Perhitungan jumlah sampel dalam peneltian ini adalah sebagai berikut.

$$
\begin{aligned}
& n=\mathrm{N} / 1+\mathrm{Ne}^{2} \ldots \ldots \ldots . . . \\
& n=109 / 1+109(0,05)^{2} \\
& n=86 \text { orang }
\end{aligned}
$$

Berdasarkan Rumus Slovin jumlah sampel yang didapat 86 responden dengan distribusi seperti terlihat pada Tabel 2.

Tabel 2.

Populasi dan Sampel

\begin{tabular}{clcc}
\hline No & \multicolumn{1}{c}{ Department } & $\begin{array}{c}\text { Jumlah } \\
\text { (Orang) }\end{array}$ & $\begin{array}{c}\text { Sampel } \\
\text { (Orang) }\end{array}$ \\
\hline 1 & Accounting Manager & 7 & 6 \\
2 & Sales and Marketing Manager & 2 & 2 \\
3 & Food and Beverage Manager & 27 & 21 \\
4 & Executive Chef & 22 & 17 \\
5 & Executive Housekeeper & 28 & 22 \\
6 & Front Office Manager & 15 & 12 \\
7 & Human Resources Coordinator & 8 & 6 \\
\hline & Total & $\mathbf{1 0 9}$ & $\mathbf{8 6}$ \\
\hline
\end{tabular}

Sumber: Human Resource Departement Kutabex Beach Front Hotel Bali, 2019

Teknik analisis data dalam penelitian ini digolongkan menjadi 2 yaitu: analisis statistik deskriptif dan analisis statistik inferensial. Analisis statistik deskriptif digunakan untuk mendeskripsikan variabel penelitian dan karakteristik responden. Analisis statistik inferensial digunakan untuk menguji hipotesis. Analisis jalur digunakan untuk menentukan hubungan 3 variabel atau lebih dalam mengkonfirmasi dan menolak hipotesis. Analisis jalur digunakan untuk menganalisis pola hubungan antar variabel dengan tujuan untuk mengetahui pengaruh langsung maupun tidak langsung variabel eksogen terhadap variabel endogen. Dasar perhitungan koefisian jalur adalah analisis korelasi dan regresi dan dalam perhitungannya menggunakan software dengan program SPSS for windows. Diagram jalur dibuat atas dasar tujuan untuk membantu menganalisis dan menginterpretasikan hubungan antar variabel yang dihipotesiskan.

\section{HASIL DAN PEMBAHASAN}

Responden penelitian ini adalah seluruh karyawan di Kutabex Beach Front Hotel Bali. Kuesioner yang disebar dalam penelitian ini sebanyak 86 kuesioner, dalam penyebaran kuesioner ini sebanyak 86 kuesioner kembali. Karakteristik 
responden dalam penelitian ini merupakan profil dari 86 responden yang berpartisipasi dalam pengisian kuesioner.

Tabel 3. menunjukkan bahwa hasil karakteristik responden yang telah diolah. Berdasarkan karakteristik jenis kelamin menunjukkan bahwa karyawan Kutabex Beach Front Hotel Bali yang menjadi responden dalam penelitian ini didominasi oleh laki-laki dibandingkan dengan perempuan. Hal tersebut dikarenakan beban pekerjaan bidang operasional merupakan bidang pekerjaan yang mengutamakan fisik yang lebih optimal jika dilakukan oleh laki-laki.

Berdasarkan karakteristik menurut usia bahwa karyawan Kutabex Beach Front Hotel Bali menunjukkan terdapat usia <21 yaitu 47,7 persen hampir sama dengan 21-30 tahun yaitu 48,8 persen tetapi hanya 3,5 persen yang berumur 31-40, hal ini menunjukkan bahwa karyawan yang bekerja di Kutabex Beach Front Hotel Bali tergolong usia muda karena dalam perusahaan jasa khususnya hotel diperlukan karyawan yang berusia muda seperti pada Front Office agar lebih menarik melayani tamu. Profil responden yang terdapat dalam kuesioner terdiri dari jenis kelamin, usia, pendidikan terakhir, serta masa kerja selama berada di dalam perusahaan terdapat pada Tabel 3.

Tabel 3.

Karakteristik Responden

\begin{tabular}{ccccc}
\hline No. & Karakteristik & Klasifikasi & $\begin{array}{c}\text { Jumlah Responden } \\
\text { (Orang) }\end{array}$ & $\begin{array}{c}\text { Persentase } \\
(\mathbf{\%})\end{array}$ \\
\hline 1 & Jenis Kelamin & Laki-laki & 49 & 57 \\
& Total & Perempuan & 37 & 43 \\
2 & & $\mathbf{8 6}$ & $\mathbf{1 0 0}$ \\
& Usia (tahun) & $<21$ & 41 & 47,7 \\
& & $21-30$ & 3 & 48,8 \\
& & $31-40$ & $\mathbf{8 6}$ & 3,5 \\
3 & Total & & 2 & $\mathbf{1 0 0}$ \\
& Pendidikan Terakhir & SMP & 53 & 2,3 \\
& & SMA/K & 25 & 61,6 \\
& & Diploma & 6 & 29,1 \\
& Total & & $\mathbf{8 6}$ & 7 \\
4 & Masa Kerja (tahun) & $<3$ & 57 & $\mathbf{1 0 0}$ \\
& & $3-5$ & 28 & 66,3 \\
& & & 1 & 32,6 \\
& Total & & $\mathbf{8 6}$ & 1,2 \\
& & & & $\mathbf{1 0 0}$ \\
\hline
\end{tabular}

Sumber: Data diolah, 2019

Berdasarkan hasil karakteristik menurut pendidikan terakhir menunjukkan bahwa karyawan Kutabex Beach Front Hotel Bali yang menjadi responden dalam penelitian ini dominan menempuh pendidikan terakhir SMA/SMK sederajat, hal ini menunjukkan karyawan Kutabex Beach Front Hotel Bali merupakan karyawan yang sudah memiliki pengalaman di bidang hospitality seperti di pendidikan SMK. Hal ini sejalan dengan jenis perusahaan ini merupakan perusahaan jasa dimana dibutuhkan karyawan-karyawan yang berkompeten di bidangnya, selain itu di Kutabex Beach Front Hotel Bali banyak menerima murid SMK melakukan training yang nantinya direkrut menjadi karyawan tetap di Kutabex Beach Front Hotel Bali. 
Pengujian validitas dilakukan dengan mengukur korelasi antar skor item instrumen dalam suatu faktor dengan skor total. Bila korelasi tiap faktor tersebut positif dan besarnya lebih dari 0,3 maka faktor tersebut merupakan konstruk yang kuat. Jadi berdasarkan analisis faktor dapat disimpulkan bahwa instrumen tersebut memiliki validitas konstruksi yang baik (Sugiyono, 2017). Tabel 4. menyajikan hasil uji validitas instrumen penelitian.

Tabel 4.

Hasil Uji Validitas

\begin{tabular}{|c|c|c|c|c|c|}
\hline No. & Variabel & Item & $\begin{array}{r}\text { Validitas } \\
\text { Korelasi Item Total }\end{array}$ & Standar & Keterangan \\
\hline \multirow[t]{8}{*}{1} & Stres Kerja $(\mathrm{X})$ & $\left(X_{1.1}\right)$ & 0,950 & 0,30 & Valid \\
\hline & & $\left(\mathrm{X}_{1,2}\right)$ & 0,945 & 0,30 & Valid \\
\hline & & $\left(\mathrm{X}_{1.3}\right)$ & 0,954 & 0,30 & Valid \\
\hline & & $\left(\mathrm{X}_{1.4}\right)$ & 0,837 & 0,30 & Valid \\
\hline & & $\left(\mathrm{X}_{1.5}\right)$ & 0,931 & 0,30 & Valid \\
\hline & & $\left(\mathrm{X}_{1.6}\right)$ & 0,871 & 0,30 & Valid \\
\hline & & $\left(X_{1.7}\right)$ & 0,943 & 0,30 & Valid \\
\hline & & $\left(\mathrm{X}_{1.8}\right)$ & 0,880 & 0,30 & Valid \\
\hline \multirow[t]{21}{*}{2} & Burnout (M) & $\left(\mathrm{M}_{1.1 .1}\right)$ & 0,831 & 0,30 & Valid \\
\hline & & $\left(\mathrm{M}_{1.1 .2}\right)$ & 0,869 & 0,30 & Valid \\
\hline & & $\left(\mathrm{M}_{1.1 .3}\right)$ & 0,870 & 0,30 & Valid \\
\hline & & $\left(\mathrm{M}_{1.1 .4}\right)$ & 0,888 & 0,30 & Valid \\
\hline & & $\left(\mathrm{M}_{1.1 .5}\right)$ & 0,907 & 0,30 & Valid \\
\hline & & $\left(M_{1.1 .6}\right)$ & 0,913 & 0,30 & Valid \\
\hline & & $\left(\mathrm{M}_{1.1 .7}\right)$ & 0,925 & 0,30 & Valid \\
\hline & & $\left(\mathrm{M}_{1.1 .8}\right)$ & 0,841 & 0,30 & Valid \\
\hline & & $\left(\mathrm{M}_{1.2 .1}\right)$ & 0,878 & 0,30 & Valid \\
\hline & & $\left(\mathrm{M}_{1.2 .2}\right)$ & 0,860 & 0,30 & Valid \\
\hline & & $\left(\mathrm{M}_{1.2 .3}\right)$ & 0,837 & 0,30 & Valid \\
\hline & & $\left(\mathrm{M}_{1.2 .4}\right)$ & 0,724 & 0,30 & Valid \\
\hline & & $\left(\mathrm{M}_{1.2 .5}\right)$ & 0,869 & 0,30 & Valid \\
\hline & & $\left(\mathrm{M}_{1.2 .6}\right)$ & 0,869 & 0,30 & Valid \\
\hline & & $\left(\mathrm{M}_{1.2 .7}\right)$ & 0,820 & 0,30 & Valid \\
\hline & & $\left(\mathrm{M}_{1.2 .8}\right)$ & 0,849 & 0,30 & Valid \\
\hline & & $\left(\mathrm{M}_{1.3 .1}\right)$ & 0,804 & 0,30 & Valid \\
\hline & & $\left(\mathrm{M}_{1.3 .2}\right)$ & 0,930 & 0,30 & Valid \\
\hline & & $\left(\mathrm{M}_{1.3 .3}\right)$ & 0,950 & 0,30 & Valid \\
\hline & & $\left(\mathrm{M}_{1.3 .4}\right)$ & 0,916 & 0,30 & Valid \\
\hline & & $\left(\mathrm{M}_{1.3 .5}\right)$ & 0,831 & 0,30 & Valid \\
\hline \multirow[t]{3}{*}{3} & Turnover & $\left(\mathrm{Y}_{1.1}\right)$ & 0,840 & 0,30 & Valid \\
\hline & $(\mathrm{Y})$ & $\left(\mathrm{Y}_{1.2}\right)$ & 0,872 & 0,30 & Valid \\
\hline & & $\left(\mathrm{Y}_{1.3}\right)$ & 0,779 & 0,30 & Valid \\
\hline
\end{tabular}

Sumber: Data diolah, 2019

Tabel 4. menunjukkan bahwa seluruh indikator pernyataan dalam variabel stres kerja, burnout, dan turnover intention memiliki korelasi tiap faktor lebih dari 0,3 sehingga seluruh indikator tersebut telah memenuhi syarat uji validitas. Reliabilitas menunjukkan sejauh mana suatu pengukuran dapat menghasilkan data yang sama (konsisten) bila dilakukan pengukuran beberapa kali terhadap obyek yang sama (Sugiyono, 2017:130). Nilai suatu instrumen dikatakan reliabel bila nilai 
Cronbach's Alpha $\geq 0,6$. Tabel 5. menyajikan hasil uji reliabilitas instrumen penelitian.

Tabel 5. menujukkan bahwa keempat instrumen penelitian yaitu stres kerja, burnout dan turnover intention memiliki nilai Cronbach's Alpha lebih besar dari 0,6 sehingga instrumen penelitian dikatakan reliabel.

Tabel 5.

Hasil Uji Reliabilitas

\begin{tabular}{|c|c|c|c|c|}
\hline \multirow[b]{2}{*}{ No. } & \multirow[b]{2}{*}{ Variabel } & \multicolumn{2}{|c|}{ Reliabilitas } & \multirow[b]{2}{*}{ Keterangan } \\
\hline & & $\begin{array}{c}\text { Cronbach's } \\
\text { Alpha }\end{array}$ & Standar & \\
\hline 1 & Stres Kerja (X) & 0,971 & 0,60 & Reliabel \\
\hline 2 & Burnout (M) & 0,957 & 0,60 & Reliabel \\
\hline 3 & Turnover Intention (Y) & 0,938 & 0,60 & Reliabel \\
\hline
\end{tabular}

Sumber: Data diolah, 2019

Data yang diperoleh dari penyebaran kuesioner perlu dideskripsikan untuk memberikan suatu interpretasi yang jelas pada data tersebut. Penetapan penilaian secara kuantitatif menggunakan skala interval dengan mengintegrasikan rata-rata skor menurut kategori penilaiannya adalah sebagai berikut.Variabel stres kerja dalam penelitian ini diukur menggunakan 8 indikator dengan 8 butir pernyataan. Hasil analisis deskriptif mengenai stres kerja dalam penelitian ini ditunjukkan dalam Tabel 6.

Tabel 6.

Deskripsi Variabel Stres Kerja (X)

\begin{tabular}{|c|c|c|c|c|c|c|c|}
\hline \multirow{2}{*}{ Indikator } & \multicolumn{5}{|c|}{ Frekuensi responden } & \multirow{2}{*}{ Mean } & \multirow{2}{*}{ Ket. } \\
\hline & 1 & 2 & 3 & 4 & 5 & & \\
\hline $\begin{array}{l}\text { Saya sering merasa tertekan dalam } \\
\text { pekerjaan }\left(X_{1.1}\right)\end{array}$ & 14 & 49 & 17 & 6 & 0 & 2,17 & Rendah \\
\hline $\begin{array}{l}\text { Kesulitan pekerjaan biasanya } \\
\text { membuat saya sulit tidur }\left(\mathrm{X}_{1.2}\right)\end{array}$ & 10 & 52 & 15 & 8 & 1 & 2,28 & Rendah \\
\hline $\begin{array}{l}\text { Pekerjaan saya membuat saya } \\
\text { gelisah }\left(\mathrm{X}_{1.3}\right)\end{array}$ & 7 & 56 & 14 & 9 & 0 & 2,29 & Rendah \\
\hline $\begin{array}{l}\text { Saya merasa lelah setelah bekerja } \\
\text { setiap hari }\left(X_{1.4}\right)\end{array}$ & 5 & 15 & 41 & 23 & 2 & 3,02 & $\begin{array}{l}\text { Cukup } \\
\text { Tinggi }\end{array}$ \\
\hline $\begin{array}{l}\text { Akan sangat membantu kesehatan } \\
\text { saya jika saya berganti pekerjaan } \\
\left(\mathrm{X}_{1.5}\right)\end{array}$ & 6 & 55 & 13 & 11 & 1 & 2,37 & Rendah \\
\hline $\begin{array}{l}\text { Saya merasa lemah saat bekerja } \\
\left(\mathrm{X}_{1.6}\right)\end{array}$ & 5 & 57 & 14 & 10 & 0 & 2,34 & Rendah \\
\hline $\begin{array}{l}\text { Saya merasa lebih emosional di } \\
\text { tempat kerja }\left(\mathrm{X}_{1.7}\right)\end{array}$ & 9 & 53 & 18 & 6 & 0 & 2,24 & Rendah \\
\hline $\begin{array}{l}\text { Saya tidak bahagia di tempat kerja } \\
\left(\mathrm{X}_{1.8}\right)\end{array}$ & 40 & 25 & 14 & 7 & 0 & 1,86 & Rendah \\
\hline Stres Kerja $(\mathrm{X})$ & & & & & & 2,32 & Rendah \\
\hline
\end{tabular}

Tabel 6. menunjukkan bahwa dari 8 indikator stres kerja diperoleh nilai sebesar 2,3. Hal ini menunjukkan bahwa tingkat stres kerja pada karyawan Kutabex Beach Front Hotel Bali tergolong dalam kategori rendah. Persepsi responden yang 
paling tinggi adalah pada pernyataan "Saya merasa lelah setelah bekerja setiap hari" dengan nilai rata-rata 3,02 hal ini menunjukkan responden cukup tinggi merasakan lelah setelah bekerja setiap hari dikarenakan tugas-tugas yang dikerjakan cukup berat setiap harinya. Sedangkan pernyataan yang memiliki nilai rata-rata paling rendah adalah "Saya tidak bahagia di tempat kerja" dengan nilai rata-rata 1,86 yang tergolong kategori rendah, hal ini menunjukkan responden merasakan tidak bahagia saat bekerja di Kutabex Beach Front Hotel Bali. Deskripsi variabel burnout dapat dilihat pada Tabel 7 .

Tabel 7.

Deskripsi Variabel Burnout (M)

\begin{tabular}{|c|c|c|c|c|c|c|c|c|}
\hline \multirow{2}{*}{\multicolumn{2}{|c|}{ Indikator }} & \multicolumn{5}{|c|}{$\begin{array}{l}\text { Frekuensi } \\
\text { responden }\end{array}$} & \multirow{2}{*}{$\begin{array}{c}M e a \\
n\end{array}$} & \multirow[t]{2}{*}{ Ket. } \\
\hline & & 1 & 2 & 3 & 4 & 5 & & \\
\hline & elelahan Emosional $\left(\mathrm{M}_{1.1}\right)$ & & & & & & 2,40 & Rendah \\
\hline $\mathrm{a}$ & $\begin{array}{l}\text { Saya merasa Lelah secara emosional } \\
\text { dalam pekerjaan saya }\left(\mathrm{M}_{1.1 .1}\right)\end{array}$ & 8 & $\begin{array}{l}4 \\
9\end{array}$ & $\begin{array}{l}2 \\
2\end{array}$ & 7 & 0 & 2,33 & Rendah \\
\hline $\mathrm{b}$ & $\begin{array}{l}\text { Saya merasa kelelahan fisik yang } \\
\text { sangat berat dalam pekerjaan saya } \\
\left(\mathrm{M}_{1.1 .2}\right)\end{array}$ & 3 & $\begin{array}{l}5 \\
6\end{array}$ & $\begin{array}{l}1 \\
9\end{array}$ & 7 & 1 & 2,38 & Rendah \\
\hline $\mathrm{c}$ & $\begin{array}{l}\text { Saya merasa lelah ketika bangun di } \\
\text { pagi hari dan harus menghadapi hari } \\
\text { lain di tempat kerja }\left(\mathrm{M}_{1.1 .3}\right)\end{array}$ & 6 & $\begin{array}{l}2 \\
5\end{array}$ & $\begin{array}{l}4 \\
1\end{array}$ & $\begin{array}{l}1 \\
3\end{array}$ & 1 & 2,74 & CukupTinggi \\
\hline$d$ & $\begin{array}{l}\text { Bekerja dengan orang-orang sepanjang } \\
\text { hari benar-benar menjadi beban bagi } \\
\text { saya }\left(\mathrm{M}_{1.1 .4}\right)\end{array}$ & 5 & $\begin{array}{l}5 \\
4\end{array}$ & $\begin{array}{l}2 \\
2\end{array}$ & 5 & 0 & 2,31 & Rendah \\
\hline $\mathrm{e}$ & $\begin{array}{l}\text { Saya merasa frustrasi dengan } \\
\text { pekerjaan saya }\left(\mathrm{M}_{1.1 .5}\right)\end{array}$ & 5 & $\begin{array}{l}5 \\
7\end{array}$ & $\begin{array}{l}1 \\
4\end{array}$ & $\begin{array}{l}1 \\
0\end{array}$ & 0 & 2,34 & Rendah \\
\hline $\mathrm{f}$ & $\begin{array}{l}\text { Saya merasa bekerja terlalu keras pada } \\
\text { pekerjaan saya }\left(\mathrm{M}_{1.1 .6}\right)\end{array}$ & 5 & $\begin{array}{l}5 \\
4\end{array}$ & $\begin{array}{l}1 \\
9\end{array}$ & 8 & 0 & 2,35 & Rendah \\
\hline $\mathrm{g}$ & $\begin{array}{l}\text { Bekerja dengan orang-orang secara } \\
\text { langsung memberi terlalu banyak } \\
\text { tekanan pada saya }\left(\mathrm{M}_{1.1 .7}\right)\end{array}$ & 8 & $\begin{array}{l}5 \\
2\end{array}$ & $\begin{array}{l}1 \\
5\end{array}$ & $\begin{array}{l}1 \\
1\end{array}$ & 0 & 2,34 & Rendah \\
\hline $\mathrm{h}$ & $\begin{array}{l}\text { Saya merasa kehabisa energi dalam } \\
\text { pekerjaan saya }\left(\mathrm{M}_{1.1 .8}\right)\end{array}$ & 8 & $\begin{array}{l}4 \\
6\end{array}$ & $\begin{array}{l}2 \\
2\end{array}$ & $\begin{array}{l}1 \\
0\end{array}$ & 0 & 2,40 & Rendah \\
\hline & ersonal Accomplishment $\left(\mathrm{M}_{1.2}\right)$ & & & & & & 2,85 & Cukup Tinggi \\
\hline & $\begin{array}{l}\text { Saya dapat dengan mudah memahami } \\
\text { tuntutan pelanggan }(\mathrm{R})\left(\mathrm{M}_{1.2 .1}\right)\end{array}$ & 2 & $\begin{array}{l}2 \\
3\end{array}$ & $\begin{array}{l}2 \\
8\end{array}$ & $\begin{array}{l}3 \\
2\end{array}$ & 1 & 3,08 & Cukup Tinggi \\
\hline $\mathrm{b}$ & $\begin{array}{l}\text { Saya menangani masalah pelanggan } \\
\text { saya dengan sangat efektif }(\mathrm{R})\left(\mathrm{M}_{1.2 .2}\right)\end{array}$ & 2 & $\begin{array}{l}2 \\
8\end{array}$ & $\begin{array}{l}4 \\
4\end{array}$ & $\begin{array}{l}1 \\
0\end{array}$ & 2 & 2,79 & Cukup Tinggi \\
\hline $\mathrm{c}$ & $\begin{array}{l}\text { Saya merasa secara positif } \\
\text { mempengaruhi kehidupan orang lain } \\
\text { melalui pekerjaan saya }(\mathrm{R})\left(\mathrm{M}_{1.2 .3}\right)\end{array}$ & 2 & $\begin{array}{l}2 \\
1\end{array}$ & $\begin{array}{l}3 \\
6\end{array}$ & $\begin{array}{l}2 \\
6\end{array}$ & 1 & 3,03 & Cukup Tinggi \\
\hline d & $\begin{array}{l}\text { Saya merasa sangat energik }(\mathrm{R}) \\
\left(\mathrm{M}_{1.2 .4}\right)\end{array}$ & 7 & $\begin{array}{l}4 \\
4\end{array}$ & $\begin{array}{l}2 \\
1\end{array}$ & $\begin{array}{l}1 \\
1\end{array}$ & 3 & 2,52 & Rendah \\
\hline & $\begin{array}{l}\text { Saya dapat dengan mudah } \\
\text { menciptakan suasana santai dengan } \\
\text { pelanggan saya }(\mathrm{R})\left(\mathrm{M}_{1.2 .5}\right)\end{array}$ & 3 & $\begin{array}{l}2 \\
5\end{array}$ & $\begin{array}{l}4 \\
1\end{array}$ & $\begin{array}{l}1 \\
4\end{array}$ & 3 & 2,87 & Cukup Tinggi \\
\hline
\end{tabular}


Lanjutan Tabel 7.

\begin{tabular}{|c|c|c|c|c|c|c|c|c|}
\hline \multirow{2}{*}{\multicolumn{2}{|c|}{ Indikator }} & \multicolumn{5}{|c|}{$\begin{array}{l}\text { Frekuensi } \\
\text { responden }\end{array}$} & \multirow{2}{*}{$\begin{array}{c}M e a \\
n\end{array}$} & \multirow[t]{2}{*}{ Ket. } \\
\hline & & 1 & 2 & 3 & 4 & 5 & & \\
\hline $\mathrm{f}$ & $\begin{array}{l}\text { Saya merasa gembira setelah bekerja } \\
\text { sama dengan pelanggan saya }(\mathrm{R}) \\
\left(\mathrm{M}_{1.2 .6}\right)\end{array}$ & 3 & $\begin{array}{l}3 \\
0\end{array}$ & $\begin{array}{l}3 \\
8\end{array}$ & $\begin{array}{l}1 \\
3\end{array}$ & 2 & 2,78 & Cukup Tinggi \\
\hline $\mathrm{g}$ & $\begin{array}{l}\text { Saya telah mencapai banyak hal } \\
\text { berharga dalam pekerjaan ini (R) } \\
\left(\mathrm{M}_{1.2 .7}\right)\end{array}$ & 6 & $\begin{array}{l}3 \\
1\end{array}$ & $\begin{array}{l}3 \\
2\end{array}$ & $\begin{array}{l}1 \\
4\end{array}$ & 3 & 2,73 & Cukup Tinggi \\
\hline h & $\begin{array}{l}\text { Dalam pekerjaan saya, saya } \\
\text { menangani masalah emosional dengan } \\
\text { sangat tenang }(\mathrm{R})\left(\mathrm{M}_{1.2 .8}\right)\end{array}$ & 9 & $\begin{array}{l}2 \\
0\end{array}$ & $\begin{array}{l}2 \\
4\end{array}$ & $\begin{array}{l}3 \\
0\end{array}$ & 3 & 2,98 & Cukup Tinggi \\
\hline & personalisasi $\left(\mathrm{M}_{1.3}\right)$ & & & & & & 2,38 & Rendah \\
\hline $\mathrm{a}$ & $\begin{array}{l}\text { Saya merasa saya memperlakukan } \\
\text { beberapa pelanggan seolah-olah } \\
\text { mereka adalah "objek" yang } \\
\text { impersonal }\left(\mathrm{M}_{1.3 .1}\right)\end{array}$ & 5 & $\begin{array}{l}4 \\
0\end{array}$ & $\begin{array}{l}2 \\
2\end{array}$ & $\begin{array}{l}1 \\
8\end{array}$ & 1 & 2,65 & Cukup Tinggi \\
\hline b & $\begin{array}{l}\text { Saya menjadi lebih tidak berperasaan } \\
\text { terhadap orang-orang sejak mengambil } \\
\text { pekerjaan ini }\left(\mathrm{M}_{1.3 .2}\right)\end{array}$ & 9 & $\begin{array}{l}5 \\
3\end{array}$ & $\begin{array}{l}1 \\
8\end{array}$ & 6 & 0 & 2,24 & Rendah \\
\hline $\mathrm{c}$ & $\begin{array}{l}\text { Saya khawatir pekerjaan ini membuat } \\
\text { saya semakin emosional }\left(\mathrm{M}_{1.3 .3}\right)\end{array}$ & $\begin{array}{l}1 \\
0\end{array}$ & $\begin{array}{l}5 \\
2\end{array}$ & $\begin{array}{l}2 \\
0\end{array}$ & 3 & 1 & 2,22 & Rendah \\
\hline d & $\begin{array}{l}\text { Saya tidak begitu peduli dengan apa } \\
\text { yang terjadi pada beberapa pelanggan } \\
\left(\mathrm{M}_{1.3 .4}\right)\end{array}$ & 8 & $\begin{array}{l}5 \\
6\end{array}$ & $\begin{array}{l}1 \\
6\end{array}$ & 6 & 0 & 2,23 & Rendah \\
\hline e & $\begin{array}{l}\text { Saya merasa pelanggan menyalahkan } \\
\text { saya untuk beberapa masalah mereka } \\
\left(\mathrm{M}_{1.3 .5}\right) \\
\text { Burnout }(\mathrm{M})\end{array}$ & $\begin{array}{l}1 \\
0\end{array}$ & $\begin{array}{l}2 \\
9\end{array}$ & $\begin{array}{l}3 \\
7\end{array}$ & $\begin{array}{l}1 \\
0\end{array}$ & 0 & 2,55 & Rendah \\
\hline
\end{tabular}

Sumber: Data diolah, 2019

Tabel 7. Menunjukkan persepsi responden yang cukup tinggi adalah terhadap indikator "personal accomplishment" dengan nilai rata-rata 2,85 sehingga tergolong kategori cukup tinggi dan butir pertanyaan dengan persepsi tertinggi juga berada pada indikator tersebut yaitu "Saya dapat dengan mudah memahami tuntutan pelanggan" dengan nilai rata-rata 3,08 yang tergolong kategori cukup tinggi ini menunjukkan responden cukup dengan dapat mudah memahami tuntutan pelanggan. Sedangkan pernyataan yang memiliki nilai rata-rata terendah adalah "Saya khawatir pekerjaan ini membuat saya semakin emosional" dengan nilai ratarata 2,22 tergolong kategori rendah ini berarti responden kurang merasa khawatir terhadap pekerjaan yang membuat semakin emosional, namun dibandingkan dengan tiga indikator lainnya indikator depersonalisasi memiliki nilai rata-rata terendah. Deskripsi variabel turnover intention dapat dilihat pada Tabel 8.

Variabel turnover intention dalam penelitian ini diukur menggunakan 3 indikator turnover intention. Hasil analisis deskriptif mengenai turnover intention dalam penelitian ini ditunjukkan dalam Tabel 8. bahwa dari 3 indikator dengan 3 pernyataan mengenai turnover intention memperoleh rata-rata sebesar 2,50 ini menunjukkan bahwa responden dari karyawan pada Kutabex Beach Front Hotel Bali memiliki keinginan untuk keluar dari perusahaan tergolong dalam kategori rendah. 
Tabel 8.

Deskripsi Variabel Turnover Intention

\begin{tabular}{|c|c|c|c|c|c|c|c|c|}
\hline \multirow{2}{*}{ No } & \multirow{2}{*}{ Indikator } & \multicolumn{5}{|c|}{ Frekuensi responden } & \multirow{2}{*}{ Mean } & \multirow{2}{*}{ Ket. } \\
\hline & & 1 & 2 & 3 & 4 & 5 & & \\
\hline 1 & $\begin{array}{l}\text { Saya sering berfikir untuk } \\
\text { meninggalkann organisasi ini } \\
\left(\mathrm{Y}_{1.1}\right)\end{array}$ & 17 & 30 & 33 & 6 & 0 & 2,33 & Rendah \\
\hline 2 & $\begin{array}{l}\text { Sangat mungkin bahwa saya akan } \\
\text { segera mencari pekerjaan baru } \\
\left(\mathrm{Y}_{1.2}\right)\end{array}$ & 3 & 39 & 37 & 7 & 0 & 2,56 & Rendah \\
\hline 3 & $\begin{array}{l}\text { Saya akan memilih untuk tetap } \\
\text { bekerja di organisasi ini }(\mathrm{R})\left(\mathrm{Y}_{1.3}\right) \\
\text { Turnover Intention }(\mathrm{Y})\end{array}$ & 21 & 18 & 21 & 25 & 1 & $\begin{array}{l}2,62 \\
2,50\end{array}$ & $\begin{array}{l}\text { Cukup } \\
\text { Tinggi } \\
\text { Rendah }\end{array}$ \\
\hline
\end{tabular}

Sumber: Data diolah, 2019

Persepsi responden yang paling tinggi adalah pada pernyataan "Saya akan memilih untuk tetap bekerja di organisasi ini" dengan nilai rata-rata 2,62 hal ini menunjukkan responden cukup tinggi dalam memilih untuk tetap bekerja di organisasi ini. Sedangkan pernyataan yang memiliki nilai rata-rata terendah adalah "Saya sering berfikir untuk meninggalkann organisasi ini" dengan nilai rata-rata 2,33 yang tergolong kategori rendah, hal ini juga menunjukkan responden memiliki sedikit berpikir untuk meninggalkan organisasi ini.

Uji normalitas pada penelitian ini dilakukan dengan menggunakan uji Kolmogorov Smirnov di mana data yang berdistribusi normal jika Asymp Sig.(2tailed) lebih besar dari 0,05. Hasil uji normalitas struktur 1 dapat dilihat pada Tabel 9.

Tabel 9.

Hasil Uji Normalitas Struktur 1

\begin{tabular}{lc}
\hline & Unstandardized Residual \\
\hline $\mathrm{N}$ & 86 \\
Kolmogorov-Smirnov & 0,816 \\
Asymp Sig. (2-tailed) & 0,518 \\
\hline Sumber: Data diolah 2019
\end{tabular}

Sumber: Data diolah, 2019

Tabel 9. menunjukkan bahwa nilai Kolmogorov-Smirnov sebesar 0,816 sedangkan nilai Asymp Sig.(2-tailed) sebesar 0,518. Hasil tersebut menunjukkan bahwa model persamaan regresi tersebut berdistribusi normal karena nilai Asymp Sig.(2-tailed) lebih besar dari $\alpha=0,05$. Hasil uji normalitas struktur 2 dapat dilihat pada Tabel 10.

Tabel 10.

Hasil Uji Normalitas Struktur 2

\begin{tabular}{lc}
\hline & Unstandardized Residual \\
\hline $\mathrm{N}$ & 86 \\
Kolmogorov-Smirnov & 1,081 \\
Asymp Sig. (2-tailed) & 0,193 \\
\hline Sumber: Data diolah, 2019 &
\end{tabular}


Tabel 10. menunjukkan bahwa nilai Kolmogorov-Smirnov sebesar 1,081 sedangkan nilai Asymp Sig.(2-tailed) sebesar 0,193. Hasil tersebut menunjukkan bahwa model persamaan regresi tersebut berdistribusi normal karena nilai Asymp Sig.(2-tailed) lebih besar dari $\alpha=0,05$.

Uji multikolinieritas digunakan untuk mengetahui ada atau tidaknya penyimpangan asumsi klasik multikolinieritas, yaitu adanya hubungan linier antar variabel eksogen dalam model regresi. Adanya multikolinieritas dapat dilihat dari nilai tolerance atau VIF. Jika nilai tolerance lebih dari 10 persen atau VIF kurang dari 10, maka dikatakan tidak ada multikolinieritas. Hasil uji multikolinearitas dapat dilihat pada Tabel 11.

Tabel 11. menunjukkan bahwa nilai tolerance dan VIF dari variabel stres kerja dan burnout menunjukkan nilai tolerance untuk setiap variabel lebih besar dari 10 persen dan nilai VIF lebih kecil dari 10 yang berarti model persamaan regresi bebas dari multikolinieritas.

Tabel 11.

Hasil Uji Multikolinieritas

\begin{tabular}{lcc}
\hline \multicolumn{1}{c}{ Variabel } & Tolerance & VIF \\
\hline Stres Kerja & 0,358 & 2,791 \\
Burnout & 0,358 & 2,791 \\
\hline Sumber: Data & & \\
\hline
\end{tabular}

Sumber: Data diolah, 2019

Uji ini digunakan untuk menguji apakah dalam model regresi terjadi ketidaksamaan varian dari residual satu pengamatan ke pengamatan yang lain. Jika nilai signifikansinya di atas 0,05 maka tidak mengandung gejala heteroskedastistas. Hasil uji heterokedastiditas struktur 1 dapat dilihat pada Tabel 12.

Tabel 12.

Hasil Uji Heteroskedastisitas Struktur 1

\begin{tabular}{|c|c|c|c|c|c|c|}
\hline \multirow[b]{2}{*}{ Model } & & \multicolumn{2}{|c|}{$\begin{array}{c}\text { Unstandardized } \\
\text { Coefficients }\end{array}$} & \multirow[t]{2}{*}{$\begin{array}{c}\text { Standardized } \\
\text { Coefficients }\end{array}$} & \multirow[b]{2}{*}{$\mathrm{t}$} & \multirow[b]{2}{*}{ Sig. } \\
\hline & & $\mathrm{B}$ & $\begin{array}{l}\text { Std. } \\
\text { Error }\end{array}$ & & & \\
\hline \multirow[t]{2}{*}{1} & $($ Constant $)$ & 0,135 & 0,078 & & 1,721 & 0,089 \\
\hline & Stres Kerja & 0,045 & 0,032 & 0,151 & 1,398 & 0,166 \\
\hline
\end{tabular}

Sumber: Data diolah, 2019

Tabel 12. menunjukkan bahwa nilai signifikansi dari variabel stres kerja sebesar 0,166. Nilai tersebut lebih besar dari 0,05 yang berarti tidak terdapat pengaruh antara variabel bebas. Dengan demikian, model penelitian ini tidak mengandung gejala heteroskedastisitas. Hasil uji heterokedastiditas struktur 2 dapat dilihat pada Tabel 13.

Tabel 13. menunjukkan bahwa nilai signifikansi dari variabel stres kerja sebesar 0,713 dan dari variabel burnout sebesar 0,416. Nilai tersebut lebih besar dari 0,05 yang berarti tidak terdapat pengaruh antara variabel bebas. Dengan demikian, model penelitian ini tidak mengandung gejala heteroskedastisitas. Hasil analisis jalur persamaan regresi 1 dapat dilihat pada Tabel 14 . 
Tabel 13.

Hasil Uji Heteroskedastisitas Struktur 2

\begin{tabular}{clccccc}
\hline & & \multicolumn{2}{c}{$\begin{array}{c}\text { Unstandardized } \\
\text { Coefficients }\end{array}$} & $\begin{array}{c}\text { Standardized } \\
\text { Coefficients }\end{array}$ & & \\
\cline { 3 - 6 } Model & & B & Etd. & & & \\
\hline \multirow{2}{*}{1} & Error & Beta & t & Sig. \\
\hline & (Constant) & 0,486 & 0,131 & & 3,720 & 0,000 \\
& Stres Kerja & $-0,023$ & 0,063 & $-0,066$ & $-0,369$ & 0,713 \\
& Burnout & $-0,068$ & 0,083 & $-0,147$ & $-0,817$ & 0,416 \\
\hline
\end{tabular}

Sumber: Data diolah, 2019

Hasil analisis jalur substruktural 1 seperti yang disajikan pada Tabel 14 . maka persamaan strukturalnya adalah sebagai berikut.

$$
\begin{array}{r}
M=\beta_{1} X+e_{1} \ldots . \\
M=0,801 X
\end{array}
$$

Tabel 14.

\begin{tabular}{|c|c|c|c|c|c|}
\hline \multirow{2}{*}{ Model } & \multicolumn{2}{|c|}{$\begin{array}{c}\text { Unstandardized } \\
\text { Coefficients }\end{array}$} & \multirow{2}{*}{$\begin{array}{c}\begin{array}{c}\text { Standardized } \\
\text { Coefficients }\end{array} \\
\text { Beta }\end{array}$} & \multirow{2}{*}{$\mathbf{t}$} & \multirow{2}{*}{ Sig. } \\
\hline & B & Std. Error & & & \\
\hline (Constant) & 1,119 & 0,121 & & 9,224 & 0,000 \\
\hline Stres Kerja (X) & 0,612 & 0,050 & 0,801 & 12,267 & 0,000 \\
\hline $\mathrm{R}^{2}$ & & & & & 0,642 \\
\hline F Hitung & & & & & 150,472 \\
\hline Sig. F & & & & & 0,000 \\
\hline
\end{tabular}

Hasil Analisis Jalur Persamaan Regresi 1

Sumber: Data diolah, 2019

Berdasarkan hasil Tabel 14. membutikan bahwa stres kerja berpengaruh positif dan signifikan terhadap burnout. Ini berarti bahwa semakin tinggi tingkat stres kerja yang dirasakan karyawan saat melakukan pekerjaan setiap hari maka akan semakin tinggi tingkat burnout yang dirasakan karyawan seperti merasakan kelelahan emosional. Tingkat burnout karyawan Kutabex Beach Front Hotel Bali dipengaruhi oleh adanya stres kerja yang dirasakan karyawan. Tingkat stres kerja sebagian besar disebabkan oleh karyawan sering merasa lelah dalam melaksanakan tugas-tugas yang diberikan setiap harinya. Hasil analisis jalur persamaan regresi 2 dapat dilihat pada Tabel 15 .

Hasil analisis jalur substruktural 2 seperti yang disajikan pada Tabel 15. maka persamaan strukturalnya adalah sebagai berikut.

$\mathrm{Y}=\beta_{2} \mathrm{X}+\beta_{3} \mathrm{M}+\mathrm{e}_{2}$

$\mathrm{Y}=0,335 \mathrm{X}+0,504 \mathrm{M}$

Berdasarkan model substruktur 1 dan substruktur 2, maka dapat disusun model diagram jalur akhir. Sebelum menyusun diagram jalur akhir, terlebih dahulu menghitung nilai standar error sebagai berikut.

$$
\begin{aligned}
& \mathrm{Pe}_{\mathrm{i}}=\sqrt{1-R i^{2}} \ldots \ldots \ldots \ldots \ldots \ldots \ldots \ldots \ldots \\
& \mathrm{Pe}_{1}=\sqrt{1-R i^{2}}=\sqrt{1-0,642}=0,598 \\
& \mathrm{Pe}_{2}=\sqrt{1-R i^{2}}=\sqrt{1-0,638}=0,6
\end{aligned}
$$


Tabel 15.

Hasil Analisis Jalur Persamaan Regresi 2

\begin{tabular}{cccccc}
\hline \multirow{2}{*}{ Model } & \multicolumn{2}{c}{$\begin{array}{c}\text { Unstandardized } \\
\text { Coefficients }\end{array}$} & $\begin{array}{c}\text { Standardized } \\
\text { Coefficients }\end{array}$ & t & Sig. \\
\cline { 2 - 4 } & B & Std. Error & Beta & & \\
\hline (Constant) & 0,399 & 0,194 & & 2,053 & 0,043 \\
Stres Kerja (X) & 0,287 & 0,094 & 0,335 & 3,040 & 0,003 \\
Burnout (M) & 0,564 & 0,123 & 0,504 & 4,571 & 0,000 \\
R $^{2}$ & & & & & 0,638 \\
F Hitung & & & & & 73,139 \\
Sig. F & & & & & 0,000 \\
\hline
\end{tabular}

Sumber: Data diolah, 2019

Berdasarkan perhitungan pengaruh error $\left(\mathrm{Pe}_{\mathrm{i}}\right)$ didapatkan hasil pengaruh error $\left(\mathrm{Pe}_{1}\right)$ sebesar 0,598 dan pengaruh error $\left(\mathrm{Pe}_{2}\right)$ sebesar 0,602. Hasil koefisien determinasi total adalah sebagai berikut.

$$
\begin{aligned}
\mathrm{R}^{2} \mathrm{~m} & =1-\left(\mathrm{Pe}_{1}\right)^{2}\left(\mathrm{Pe}_{2}\right)^{2} \ldots \ldots \\
& =1-(0,598)^{2}(0,602)^{2} \\
& =1-(0,358)(0,362) \\
& =1-0,130 \\
& =0,870
\end{aligned}
$$

Nilai determinasi total sebesar 0,870 mempunyai arti bahwa sebesar 87,0 persen variasi turnover intention karyawan dipengaruhi oleh variasi stres kerja dan variasi burnout, sedangkan sisanya 13,0 persen dijelaskan oleh faktor lain yang tidak dimasukkan ke dalam model.

Hasil analisis hipotesis menunjukkan bahwa burnout berpengaruh positif dan signifikan terhadap turnover intention, pada Tabel 15. menunjukkan bahwa semakin tinggi tingkat burnout yang dirasakan karyawan maka semakin tinggi tingkat turnover intention atau tingginya niat keinginan karyawan untuk keluar dari perusahaan. Dalam hal ini, tingkat burnout disebabkan karena karyawan merasa khawatir terhadap pekerjaan yang didapatkan membuat karyawan merasa semakin emosional sehingga menyebabkan karyawan memiliki keinginan untuk mencari pekerjaan di tempat lain. Sebaiknya tingkat burnout terhadap karyawan perlu diturunkan untuk mengurangi tingkat turnover intention pada Kutabex Beach Front Hotel Bali. Penelitian ini sejalan dengan penelitian yang dilakukan oleh Weisberg (1994); Sakka (2016) menyatakan bahwa adanya pengaruh positif dan signifikan antara burnout dengan turnover intention, bahwa karyawan yang memiliki tingkat burnout yang tinggi maka karyawan tersebut akan berfikir untuk meninggalkan perusahaan. Hasil ini juga didukung oleh penelitian Zhang \& Feng (2011); Jacob (1994) menyatakan bahwa terdapat hubungan positif dan signifikan antara burnout terhadap turnover intention. Rangkuman hasil uji dapat dilihat pada Tabel 16.

Berdasarkan hasil perhitungan menunjukkan bahwa hasil tabulasi $\mathrm{Z}=14,85$ $>$ 1,96 yang berarti variabel mediator yakni burnout dinilai secara signifikansi memediasi secara parsial hubungan antara stres kerja terhadap turnover intention karyawan. Nilai VAF (54,7 persen) lebih dari 20 persen, maka dapat dijelaskan 
bahwa ada efek mediasi atau dengan kata lain burnout secara parsial memediasi hubungan antara stres kerja terhadap turnover intention (partial mediation).

Tabel 16.

Rangkuman Hasil Uji

\begin{tabular}{cccc}
\hline $\begin{array}{c}\text { Pengaruh } \\
\text { Variabel }\end{array}$ & $\begin{array}{c}\text { Pengaruh } \\
\text { Langsung }\end{array}$ & $\begin{array}{c}\text { Pengaruh Tidak Langsung Melalui } \\
\text { Burnout }(\mathbf{M})\left(\boldsymbol{\beta}_{\mathbf{1}} \times \boldsymbol{\beta}_{\mathbf{3}}\right)\end{array}$ & $\begin{array}{c}\text { Pengaruh } \\
\text { Total }\end{array}$ \\
\hline $\mathrm{X} \rightarrow \mathrm{M}$ & 0,801 & - & 0,801 \\
$\mathrm{X} \rightarrow \mathrm{Y}$ & 0,335 & 0,404 & 0,739 \\
$\mathrm{M} \rightarrow \mathrm{Y}$ & 0,504 & - & 0,504 \\
\hline
\end{tabular}

Sumber: Data diolah, 2019

Tingkat stres kerja perlu diturunkan untuk mengurangi terjadinya tingkat burnout yang dirasakan karyawan Kutabex Beach Front Hotel Bali. Hasil ini didukung penelitian yang dilakukan oleh Enshassi \& Alkilani (2015); Satriyo \& Survival (2014); Tawiah et al. (2016) bahwa stres kerja berpengaruh positif dan signifikan terhadap burnout. Hasil ini juga didukung penelitian yang dilakukan oleh Kreitner \& Kinicki (2004) yang menyatakan bahwa salah satu hasil dari stres secara psikologis adalah burnout. Penelitian Hobfoll (1989) menunjukkan bahwa stres yang luar biasa tinggi atau kronis akan mempengaruhi individu sehingga mengalami kelelahan (burnout).

Berdasarkan pengujian hipotesis pengaruh stres kerja terhadap turnover intention menyatakan bahwa dalam penelitian ini mendapatkan hasil bahwa stres kerja berpengaruh positif dan signifikan terhadap turnover intention. Hasil tersebut terlihat pada Tabel 15. yang memperlihatkan berarti bahwa semakin tinggi tingkat stres kerja yang dirasakan karyawan maka semakin tinggi tingkat turnover intention atau tingginya niat keinginan karyawan untuk keluar dari perusahaan. Tingkat turnover intention karyawan Kutabex Beach Front Hotel Bali disebabkan oleh adanya stres kerja yang dirasakan karyawan karena merasakan kelelahan dalam melakukan pekerjaan.

Dalam hal ini, tingkat stres kerja sebagian besar disebabkan oleh karyawan sering merasa lelah dalam melaksanakan tugas-tugas yang diberikan setiap harinya. Tingkat stres kerja perlu diturunkan untuk memperkecil tingginya tingkat turnover intention pada Kutabex Beach Front Hotel Bali. Penelitian ini sesuai dengan penelitian yang dilakukan oleh Parvaiz et al. (2015); Akinboye \& Adeyemo (2002) Mitchell et al. (2014); Nazenin \& Palupiningdyah (2014); Rehman \& Mubashar (2017) menyatakan bahwa stres kerja berpengaruh positif terhadap turnover intention, apabila karyawan merasa tertekan terhadap pekerjaannya maka karyawan tersebut akan memiliki keinginan untuk meninggalkan perusahaan.

Hasil ini juga didukung penelitian yang dilakukan oleh Mosadeghrad (2012); Shahzad et al. (2011); Siddiqui dan Raja (2015) menyatakan bahwa semakin tinggi tingkat stres kerja yang dirasakan karyawan maka semakin tinggi juga tingkat turnover intention yang terjadi. Penelitian menurut Syahronica et al. (2015) menyatakan bahwa semakin banyaknya kebutuhan hidup yang harus terpenuhi dan persaingan kerja yang semakin ketat dapat menimbulkan stres kerja yang akhirnya memicu turnover intention karyawan. 
Hasil analisis hipotesis memperoleh hasil bahwa secara signifikan burnout memediasi secara parsial pengaruh stres kerja terhadap turnover intention. Pada penelitian sebelumnya mendapatkan stres kerja berpengaruh positif dan signifikan terhadap burnout dan burnout berpengaruh positif dan signifikan terhadap turnover intention, sehingga dapat dikatakan bahwa burnout secara parsial memediasi pengaruh stres kerja terhadap turnover intention. Peran burnout sebagai variabel mediasi yaitu untuk mengetahui hubungan antara stres kerja terhadap burnout dan hubungan turnover intention terhadap burnout. Dalam penelitian ini burnout mendapatkan hasil yang tinggi, jadi burnout dikatakan sebagai variabel mediasi karena untuk mendapatkan hasil turnover intention yang rendah harus terlebih dahulu menurunkan tingkat burnout maka tingkat stres kerja akan menurun yang nantinya akan menurunkan tingkat turnover intention. Seperti yang dinyatakan oleh Lee \& Ashforth (1993); Lin \& Moncrief (2013) bahwa burnout memiliki efek mediasi antara stres kerja dan turnover intention. Penelitian ini juga didukung oleh penelitian yang dilakukan Tawiah et al. (2016); Ahmad \& Afgan (2016); Kim (2008) yang menyatakan bahwa stres kerja berpengaruh positif dan signifikan terhadap turnover intention yang dimediasi oleh burnout.

Hasil penelitian ini menunjukkan bahwa stres kerja berpengaruh secara langsung terhadap turnover intention, maupun secara tidak langsung melalui burnout. Secara teoritis, hasil penelitian ini jika dikaitkan dengan Social Exchange Theory, maka dapat dikatakan perusahaan harus memperhatikan hubungan timbal balik antar karyawan sehingga nantinya akan menimbulkan rendahnya niat untuk meninggalkan perusahaan.

Temuan penelitian ini memberikan implikasi terhadap strategi pengembangan sumber daya manusia di Kutabex Beach Front Hotel Bali untuk lebih memperhatikan indikator-indikator stres kerja dan burnout. Terutama yang harus diperhatikan yaitu kelelahan saat bekerja, dengan cara perusahaan harus memperhatikan kemampuan setiap karyawan agar sesuai dengan pekerjaan yang dilakukan dan pada variabel burnout yang harus diperhatikan adalah kelelahan emosional atau kejenuhan kerja, dengan cara perusahaan harus memperhatikan lingkungan eksternal dan lingkungan internal perusahaan agar karyawan tidak merasakan kejenuhan kerja hingga mengalami kelelahan emosional. Sehingga penelitian ini diharapkan dapat digunakan sebagai bahan pertimbangan para pengambil keputusan dalam menekan tingkat turnover karyawan dengan cara menurunkan turnover intention karyawan.

\section{SIMPULAN}

Stres kerja berpengeruh positif dan signifikan terhadap burnout di Kutabex Beach Front Hotel Bali, dimana karyawan yang merasakan stres kerja yang tinggi atau kronis akan mempengaruhi karyawan sehingga mengalami burnout. Stres kerja berpengaruh positif dan signifikan terhadap turnover intention pada karyawan Kutabex Beach Front Hotel Bali, hal ini menunjukkan bahwa karyawan yang merasakan stres kerja yang tinggi akan menimbulkan tingkat turnover intention yang terjadi/tinggi. Burnout berpengaruh positif dan signifikan terhadap turnover intention karyawan Kutabex Beach Front Hotel Bali, hal ini menunjukkan bahwa karyawan yang merasakan tingkat burnout yang tinggi maka akan menimbulkan 
niat untuk keluar dari perusahaan yang tinggi, begitupun sebaliknya apabila tingkat burnout yang dirasakan karyawan rendah maka timbulnya niat untuk keluar dari perusahaan akan rendah. Burnout memediasi secara parsial pengaruh antara stres kerja terhadap turnover intention di Kutabex Beach Front Hotel Bali, hal ini menunjukkan bahwa semakin tinggi stres kerja di perusahaan, maka akan semakin tinggi juga tingkat burnout karyawan dan turnover intention karyawan pun menjadi semakin tinggi.

Saran dapat diarahkan pada memperhatikan karyawan yang merasa kelelahan saat bekerja setiap hari, agar dapat memperhatikan kemampuan karyawan dalam menyelesaikan tugas yang diberikan. Kutabex Beach Front Hotel Bali dapat memperhatikan karyawannya dengan cara menganalisis kembali beban kerja karyawan atau lebih memperhatikan jumlah karyawan sesuai dengan department agar karyawan mendapatkan pekerjaan sesuai dengan kebutuhan. Maka hal tersebut akan mengurangi tingkat stres kerja pada karyawan yang nantinya akan berdampak pada menurunnya tingkat turnover intention, karena indikator "Saya merasa lelah setelah bekerja setiap hari" merupakan indikator dengan nilai rata-rata tertinggi pada deskripsi variabel stres kerja. Memperhatikan mengenai burnout karyawan terhadap respon yang dirasakan. Kutabex Beach Front Hotel Bali seharusnya dapat memperhatikan respon yang diberikan terhadap karyawan yang nantinya karyawan bisa dengan mudah memahami tuntutan pelanggan. Selain itu, dengan memberikan pelatihan bagi karyawan di dalam mengatasi pelanggan yang nantinya membuat karyawan dengan mudah memahami tuntutan pelanggan, ditambah dengan pemberian reward sebagai bentuk apresiasi apabila sudah melewati target dalam melakukan pekerjaan. Hal ini akan dapat menurunkan tingkat turnover intention pada Kutabex Beach Front Hotel Bali. Memperhatikan mengenai turnover intention pada Kutabex Beach Front Hotel Bali terhadap karyawan yang memilih untuk meninggalkan perusahaan. Dalam hal ini pihak Kutabex Beach Front Hotel Bali harus mengurangi tingkat stres kerja dan burnout yang dirasakan karyawan dengan lebih memperhatikan beban kerja yang diberikan bagi karyawan, sehingga akan menurunkan tingkat turnover intention karyawan Kutabex Beach Front Hotel Bali. Perusahaan disarankan untuk lebih membangun rasa hormat karyawan dengan bijak agar karyawan tidak memiliki niat untuk pindah bekerja pada waktu yang akan datang.

\section{REFERENSI}

Adenguga, R. A., Adenguga F. T., \& Ayodele, K. O. (2013). Organizational Commitment and Turnover Intention Among 'Private Universities' Employees In Ogun State, Nigeria. Open Journal of Education, 1(2), 31-36.

Ahmad. A., \& Afgan, S. (2016). The Relationship of Job Stress and Turnover Intention In Commercial Banks of Pakistan by Assesing the Mediating Role of Burnout. Journal of Business Strategis, 10(1), 1-23.

Akinboye, J. O., \& Adeyemo, D. A. (2002). Coping With Stress in Life and Workplace. Ibadan: Sterling-Horden Publishers. 
Ardana, I. K., Mujiati, N. W., \& Utama, I. W. M. (2012). Manajemen Sumber Daya Manusia. (Edisi Pertama). Yogyakarta: Graha Ilmu.

Blau, P. (1964). Exchange and Power in Social Life. New York: Wiley \& Sons.

Chandio, J. A., Jhatial, A. A. \& Mallah, R. (2013). Modeling The Relationship of Unclear Career Development With Job Dissatisfaction, Job Stres And Employees Turnover Intention: Structural Equation Modeling Approach. Journal of Arts Humamanities, 41(41), 55-57.

Coyle, S. J., \& Parzefall, M. (2008). Psychological contracts. In: Cooper, Cary L. and Barling, Julian, (eds.). The Sage Handbook of Organizational Behaviour. London, UK : SAGE Publications.

Eduard, Y. T. (2011). Konsekuensi Konflik Peran, Kelebihan Beban Kerja dan Motivasi Intrinsik terhadap Burnout pada Dosen yang Merangkap Jabatan Struktural. Jurnal Asset, 13(2), 111-122.

Enshassi, A., El-Rayyes, Y., \& Alkilani, S. (2015). Job stress, Job Burnout and Safety Performance in the Palestinian Construction Industry. Journal of Financial Management of Property and Construction, 20(2), 170-187.

Fahrizal., \& Utama, I. W. M. (2017). Pengaruh Persepsi Dukungan Organisasi Terhadap Komitmen Organisasional Dan Turnover Intention Karyawan Hotel Kajane Mua Ubud. E-Jurnal Manajemen Unud, 6(10), 5405-5431.

Fried, Y., Shirom, A., Gilboa, S., \& Cooper, L. C. (2008). The Mediating Effect of Job Satisfactionand Propensity to Leave on Role Stress Job Performance Relationship: Combining Meta Analysis and Structural Equation Modeling. International Journal of Stress Management, 15(4), 305-328.

Fung, N. S., Ahmad, A. \& Omar, Z. (2012). Work-Family Enrichment: It's Mediating Role in the Relationships between Dispositional Factors and Job Satisfaction. International Journal of Academic Research in Business and Social Sciences, 2(11), 73-88.

Gonul, K. O. \& Ceyhun, G. C. (2014). The Impact of Job Characteristics on Burnout; The Mediating Role of Work Family Conflict and the Moderating Role of Job Satisfaction. International Journal of Academic Research in Management, 3(3), 291-309.

Hobfoll, S. E. (1989). Conservation Of Resources: A New Attempt At Conceptualizing Stress. American Psychologist, 44(3), 513-524.

Hlatywayo, C. K., Mlanga, T. S. \& Zingwe, T. (2014). Precursors Of Emotional Stability, Stress And Work-Family Conflict Among Female Bank 
Employees. International Business \& Economics Research Journal. 13(4), 861-866.

Jia, L., Shaw, J. D., Tsui, A. S., \& Park, T. Y. (2014). A Social-Structural Perspective on Employee-Organization Relationships and Team Creativity. Academy of Management Journal, 57(3), 869-891.

Kim, H. S. M. (2008). Burnout and Turnover Intention Among Social Workers: Effects of Role Stress, Job Autonomy and Social Support.Administration in Social Work, 32(3), 5-25.

Kreitner, R. \& Kinicki. (2008). Organizational Behavior ( ${ }^{\text {th }}$ Edition). Boston: McGraw-Hill.

Kumar, R., Charles, R., \& Peter, Y. (2012). A Study on Turnover intention in Fast Food Industry: Employees Fit to the Organizational Culture and the Important of their Commitment. International Journal of Academic Research in Business and Social, 2(5), 9-42.

Lee, R. T. \& Ashfroth, B. E. (1993). Sebuah Pemeriksaan Lebih Lanjut Dari Manajerial Burnout: Menuju Model Terpadu. Jurnal Perilaku Organisasi, 14(4), 3-20.

Lin, G. S., Cravens, D. W., Grant, K. \& Moncrief, W. C. (2013). Antecedents And Consequences of Salesperson Burnout. European Journal of Marketing, 35(11), 587-611.

Liu, W., Zhao, S., Shi, L., Zhang, Z., Liu, X., Li, L., Duan, X., Li, G., Lou, F., Jia, X., Fan, L., Sun, T., \& Ni, X. (2018). Workplace Violence, Job Satisfaction, Burnout, Perceived Organisational Support And Their Effects On Turnover Intention Among Chinese Nurses In Tertiary Hospitals: Across-Sectional Study. Health Policy Reseacrh, 8(6), 1-11.

Liu, H. L., \& Lo, V. H. (2017). An Integrated Model of Workload, Autonomy, Burnout, Job Satisfaction, and Turnover Intention Among Taiwanese Reporters. Asian Journal of Communication, 28(2), 1-17.

Mangkunegara, A. A. P. (2011). Manajemen Sumber Daya Manusia Perusahaan. Bandung: PT. Remaja Rosdakarya.

Madziatul, C. (2011). Pengaruh Konflik Peran, Kelelahan Emosional terhadap Kepuasan Kerja dan Komitmen Organisasi. Jurnal Ekonomi Bisnis. 16(2), $145-154$.

Maharani, P. A., \& Triyoga, A. (2012). Kejenuhan Kerja (Burnout) dengan Kinerja Perawat dalam Pemberian Asuhan Keperawatan. Jurnal STIKES, 5(2), 167-178. 
Maslach, C., \& Jackson, S. E. (1981). The Measurement of Experienced Burnout. Journal of organizational behavior, 2(2), 99-113.

Mitchell, O., Mackenzie, D. L., Styve, G. J., \& Gover, A. (2014). The Impact of Individual, Organizational and Environmental Attributes on Voluntary Turnover Among Juvenile Correctional Staf Members. Justice Quarterly: Academy of Criminal Justice Science, 17(2), 332-357.

Mosadeghrad, A. M. (2012). A Study Of Relationship Between Job Stres, Quality Of Working Life And Turnover Intention Among Employees. Human Resources Management International Digest, 20(3), 77-100.

Nazenin, S., \& Palupiningdyah. (2014). Peran Stres Kerja dan Kepuasan Kerja Untuk Mengurangi Turnover Intention. Jurnal Dinamika Manajemen, 5(2), 220-227.

Parvaiz, L., Saba, B., Ambar, K., \& Yasir, A.F. (2015). Impact of Stressors (Role conflict, Role overload, Leadership Support and Organizational Politics) on Job Stress and its Subsequent Impact on Turnover Intention. International Journal of Business and Management Invention, 4(10), 52-63.

Paillé, P., \& Mejia-Morelos, J. H. (2014). Antecedens of Pro-environmental Behaviours at Work: The moderating Influence of Psychological Contract Breach. Journal of Environmental Psychology, 38(5), 124-131.

Qureshi, M. I. , Raja, A. J., Mehwish, I., Sadia, A., Saeed, L., Imran, N., \& Khalid, Z. (2012). Job Stress, Workload, Environment and Employees Turnover Intentions: Destiny or Choice. Archives Des Sciences, 65(8), 230-241.

Rehman, N., \& Mubashar, T. (2017). Job stress, Psychological Capital and Turnover Intentions in Employees of Hospitality Industry. Journal of Behavioural Sciences, 27(2), 59-79.

Satriyo, M., \& Survival, (2014). Pengaruh Stres Kerja Terhadap Burnout dan Pengaruh Burnout Terhadap Kinerja. Jurnal Manajemen \& Akuntansi. 3(2), 52-61.

Satrio, M. I. B., \& Surya, I. B. K. (2018). The Role Of Organizational Commitment In Mediating The Effect Of Job Satisfaction And Perceived Organizational Support On Turnover Intention. International Journal of Social Science and Humanities Research, 6(4), 1240-1247.

Sartika, D. (2014). Pengaruh Kepuasan Kerja Dan Gaya Kepemimpinan Transformasional Terhadap Keinginan Keluar Karyawan Dengan Komitmen Organisasi Sebagai Variabel Mediasi (Studi Kasus Di CV Putra Tama Jaya). Management Analysis Journal, 3(2), 25-34. 
Sakka, E. N. (2016). The Relationship Between Person Organization Fit, Burnout, And Turnover Intention Among CIC Academic Staff. The Business \& Management Review, 7(2), 53.

Sugiyono. (2017). Metode Penelitian Kuantitatif, Kualitatif, Dan $R \& D$. Bandung: Alfabeta.

Shahzad, K., Hayat, K., Abbas, M., \& Bashir, S. (2011). Antecedents of Turnover and Absenteeism: Evidence from Public Sector Institutions of Pakistan. Interdisciplinary Journal Of Contemporary Research In Business, 2(9), 108-120.

Sidharta, N. (2011). Dampak Komitmen Organisasi dan Kepuasan Kerja terhadap Turnover intention: Studi Empiris pada karyawan bagian operator di salah satu perusahaan Garment di Cimahi. Jurnal Manajemen, 10(2), 129-142.

Siddiqui, A. A., \& Raja, A. J. (2015). Antecedents Of Employees Turnover Intentions: Evidence From Private Educational Institutions. American Journal of Economics and Business Administration, 7(4), 160-165.

Syahronica, G., Hakam, M. S. \& Ruhana, I. (2015). Pengaruh Kepuasan Kerja dan Stres Kerja terhadap Turnover Intention (studi pada karyawan departemen dunia fantasi PT. pembangunan jaya Ancol, tbk). Jurnal administrasi bisnis, 20(1), 1-6.

Tawiah, K. A., Annor, F., \& Arthur, B. G., (2016). Linking Commuting Stress To Job Satisfaction And Turnover Intention: The Mediating Role Of Burnout, Journal of Workplace Behavioral Health, 31(2), 104-123.

Tienne, K. B. D., Agle, B. R., Phillips, J. C., \& Ingerson, M. (2012). The Impact of Moral Stress Compared to Other Stressors on Employee Fatigue, Job Satisfaction, and Turnover: An Empirical Investigation. Journal of Business Ethics, 110(3), 377-391.

Utama, M. S. (2016). Aplikasi Analisis Kuantitatif. Denpasar: Sastra Utama.

Widodo, S. E. (2015). Manajemen Pengembangan Sumber Daya Manusia. Yogyakarta. Pustaka Pelajar.

Weisberg, J. (1994). Measuring Workers Burnout And Intention To Leave. International Journal of Manpower, 15(1), 4-5.

Yuda, I. B. D. P., \& Ardana, I. K. (2017). Pengaruh Kepuasan Kerja Dan Stres Kerja Terhadap Turnover Intention pada Karyawan Hotel Holiday Inn Express. EJurnal Manajemen Unud, 6(10), 5319-5347. 
E-Jurnal Manajemen, Vol. 9, No. 6, 2020 : 2308-2331

Zhang, Y. \& Feng, X. (2011). The Relationship Between Job Satisfaction, Burnout, And Turnover Intention Among Physicians From Urban State-Owned Medical Instutions In Hubei, China: A Cross-Sectional Study. Journal BMC Health Services Research, 11(5), 235-236. 